\title{
Optimizing soil nitrogen balance in a potato cropping system through legume intercropping
}

\author{
Shadrack O. Nyawade • Nancy N. Karanja • Charles K. K. Gachene • \\ Harun I. Gitari · Elmar Schulte-Geldermann • Monica Parker
}

Received: 4 February 2019/Accepted: 24 February 2020/Published online: 12 March 2020

(C) The Author(s) 2020

\begin{abstract}
Negative nitrogen balance represents a major factor causing low potato yield in potato growing areas of Kenya while its excessive surplus poses a significant environmental concern. In order to synchronize this tradeoff, a field trial integrating potato (Solanum tuberosum L.) with lima bean (Phaseolus lunatus L.) and dolichos (Lablab purpureus L.) in intercropping system was conducted in the upper midland [1552 $\mathrm{m}$ above sea level (masl), lower highland (1894 masl) and upper highland
\end{abstract}

Electronic supplementary material The online version of this article (https://doi.org/10.1007/s10705-020-10054-0) contains supplementary material, which is available to authorized users.

S. O. Nyawade $(\varangle) \cdot$ M. Parker

The CGIAR Research Program on Climate Change, Agriculture and Food Security (CCAFS), International Potato Center (CIP), Sub-Saharan Africa Regional Office, ILRI Campus, Old Naivasha Road,

P.O. Box 25171, Nairobi 00603, Kenya

e-mail: shadnyawade@gmail.com

S. O. Nyawade · N. N. Karanja · C. K. K. Gachene Department of Land Resource Management and Agricultural Technology, College of Agriculture and Veterinary Sciences, University of Nairobi, P.O. Box 29053-00625, Nairobi, Kenya

H. I. Gitari · E. Schulte-Geldermann · M. Parker The CGIAR Research Program on Roots, Tubers and Bananas (RTB), International Potato Center (CIP), SubSaharan Africa Regional Office, ILRI Campus, Old Naivasha Road, P.O. Box 25171, Nairobi 00603, Kenya
(2552 masl)] agro-ecological zones of Kenya. Nitrogen gains from mineralization, fertilization, biological fixation, and outputs from biomass accumulation, leaching, volatilization and soil erosion were quantified using standard procedures. Soil $\mathrm{N}$ balance ranged from -10.7 to $-18.1 \mathrm{~kg} \mathrm{~N}$ ha $^{-1}$ for sole potato, 4.1 to $6.6 \mathrm{~kg} \mathrm{~N} \mathrm{ha}^{-1}$ for intercropping and 2.9 to $22.3 \mathrm{~kg} \mathrm{~N} \mathrm{ha}^{-1}$ for sole legumes. The intermediate range of polyphenol and lignin contents in intercropping enhanced $\mathrm{N}$ mineralization with peak $\mathrm{N}$ release of

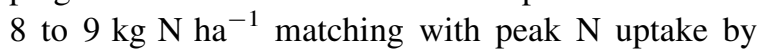
potato (19.9 to $31.2 \mathrm{~kg} \mathrm{~N} \mathrm{ha}^{-1}$ ). Nitrate was leached below the active root zone in sole potato cropping (4.2 to $46.6 \mathrm{~kg} \mathrm{~N} \mathrm{ha}^{-1}$ ), a process that was diverged by the

\section{H. I. Gitari \\ Department of Agricultural Science and Technology, \\ School of Agriculture and Enterprise Development, \\ Kenyatta University, P.O. Box 43844-00100, Nairobi, \\ Kenya \\ E. Schulte-Geldermann \\ University of Applied Science Bingen (TH Bingen), \\ Berlinstrasse 109, 55411 Bingen, Germany}


deep root systems of legume intercrops. These results suggest that legume intercropping can provide a means of balancing the nitrogen retained in the biomass and soil, thus offering a mechanism for optimizing the soil $\mathrm{N}$ balance in smallholder potato farming systems.

Keywords Legume intercropping - Nitrogen balance $\cdot$ Nitrogen mineralization $\cdot$ Nitrogen uptake

\section{Introduction}

Nitrogen is one of the most important nutrients constraining potato production in subtropical smallholder farming systems (Sanchez 2002; Henao and Baanante 2006; Burke 2017). The $\mathrm{N}$ balances in these systems are on average negative as the $\mathrm{N}$ outflows often exceed the $\mathrm{N}$ inflows. The $\mathrm{N}$ inflows in a potato production system are majorly from inorganic fertilizers, organic manures or additions through biological nitrogen fixation where legumes are integrated in rotation or intercropping systems (Shekofteh et al. 2013; Jégo et al. 2008). The outflow processes include $\mathrm{N}$ removal by soil erosion and in harvested biomass, denitrification during prolonged periods of wet soil, and volatilization of ammonia $\left(\mathrm{NH}_{3}\right)$ in high $\mathrm{pH}$ soils after surface granular urea application (Loomis and Connor 1992). Leaching occurs mainly where nitrates leave the soil in drainage water (Arregui and Quemada 2006).

Defining an appropriate fertilizer application rate that matches $\mathrm{N}$ supply with crop $\mathrm{N}$ demand is thus necessary in smallholder potato farming systems to avoid $\mathrm{N}$ mining. This is only possible if knowledge of the quantity of $\mathrm{N}$ that will be supplied by the crop residues is known. This process is defined by the soil temperature and soil water contents, residue chemical composition: lignin (L), polyphenol (P), carbon (C), nitrogen $(\mathrm{N})$ and their ratios such as C-to-N, L-to-N, and L + P-to-N (Tian et al. 1993; Mitchell et al. 2000; Palm and Sanchez 1991; Becker and Ladha 1997). Where decomposed organic matter exhibits high C-to$\mathrm{N}$, lignin-to- $\mathrm{N}$, and polyphenol-to- $\mathrm{N}$ ratios, $\mathrm{N}$ supply will not be sufficient to satisfy $\mathrm{N}$ requirements of soil microorganisms, resulting in net $\mathrm{N}$ immobilization (Lupwayi and Haque 1999; Lupwayi et al. 2006). The production and retention of available $\mathrm{N}$ often increases with increasing soil moisture and soil temperature to a threshold and thereafter declines (Baldock et al. 2018).

In Kenya, the low soil $\mathrm{N}$ content is aggravated by the poor potato cropping systems that majorly entail sole cropping with limited capacity to provide adequate soil cover and protect soil from erosion (Nyawade et al. 2018b; Gitari et al. 2018a, b, 2019; Muthoni et al. 2013). The nitrogen input not assimilated by potato crop accumulates in the soil as nitrate that is leached through irrigation and rainwater or lost through volatilization or denitrification (Gentile et al. 2009). To compensate for these $\mathrm{N}$ losses, a number of farmers have opted to do heavy application of inorganic $\mathrm{N}$ fertilizer (Kimetu et al. 2006; Muthoni et al. 2013). This strategy is too expensive for the smallholder farmers and may contribute to increased environmental pollution through eutrophication. In addition, majority of potato produced in Kenya is rainfed and grown under conditions where availability of water defines the potential productivity. In such conditions, provision of an appropriate supply of $\mathrm{N}$ should be synchronized with the temporal demand for the crop over a growing season. This is true as $\mathrm{N}$ makes up $1-4 \%$ of potato dry matter while too much $\mathrm{N}$ results in vigorous early vegetative growth leading to haying-off under water-limited conditions (van Herwaarden et al. 1998).

There is therefore a growing need to design lowcost and efficient integrated nitrogen management systems compatible with smallholder farmers' socioeconomic status. In this context, legumes or nitrogenrich plant residues present promising alternatives to the mineral fertilizers. These crops can be simultaneously introduced into potato cropping systems. The organic residues from these systems must decompose fast enough for $\mathrm{N}$ to become available to potato crop. In this way, synchronization of $\mathrm{N}$ supply and crop $\mathrm{N}$ demand for a given target yield level may reduce $\mathrm{N}$ losses and increase $\mathrm{N}$ use efficiency. Intercropping that includes deep rooted crops can reduce nitrate leaching due to their ability to effectively take up residual nitrogen, converting it into crop biomass which is later mineralized for nitrogen release (PlazaBonilla et al. 2015; Constantin et al. 2012).

Intercropping potato with high nitrogen fixing legumes can alleviate the high cost of inorganic soil nitrogen inputs (Burke 2017). Sanginga and Woomer (2009) reported that velvet bean (Mucuna pruriens L.) accumulated about $160 \mathrm{~kg} \mathrm{~N} \mathrm{ha}^{-1}$ in 12 weeks when 
it was intercropped with maize, while Eaglesham et al. (1981) found that the nitrogen fixed by companion cowpea was about $41 \mathrm{~kg} \mathrm{~N} \mathrm{ha}^{-1}$ in maize-cowpea intercropping system. Roots of legumes can decompose and release nitrogen into the soil where it is made available for subsequent crops (Giller 2015). Legume cover crop integration into potato cropping systems can appreciably reduce nitrogen losses due to soil erosion thereby increasing efficiency of nitrogen use (Xing et al. 2011).

Intercropping is however practiced by only about $5-12 \%$ of the smallholder farmers in Kenya and mostly with maize (Zea mays L.) intercrop (Muthoni et al. 2013). We therefore conducted a two-year field experiment to compare the soil nitrogen content of sole potato and potato intercropped with lima bean (Phaseolus lunatus L.) or dolichos (Labalab purpureus L.) in three agro-ecological zones of Kenya (upper midland, lower highland and upper highland). We hypothesized that (1) legume intercropping increases the amount of dry matter available for nitrogen mineralization thus increasing the soil nitrogen content available for uptake by potato crop and (2) that legume intercropping minimizes the amount of $\mathrm{N}$ lost to leaching and soil erosion thus increasing the soil $\mathrm{N}$ balance.

\section{Materials and methods}

Site description

The trials were carried out during the four rainy seasons of 2017 and 2018 in three agro-ecological zones of Kenya; upper midland-Kirinyaga [1552 m above sea level (masl)], lower highland-Kabete (1854 masl) and upper-highland-Nyandarua (2553 masl). Nyandarua site lies along latitude $0^{\circ} 14^{\prime} 39.08^{\prime \prime} \mathrm{S}$ and longitude $36^{\circ} 17^{\prime} 18.99^{\prime \prime} \mathrm{E}$, Kirinyaga, $0^{\circ} 29^{\prime} 35.71^{\prime \prime} \mathrm{S}$ and $37^{\circ} 20^{\prime} 55.29^{\prime \prime} \mathrm{E}$ and Kabete $1^{\circ} 14^{\prime} 45.00^{\prime \prime} \mathrm{S}$ and $36^{\circ} 44^{\prime} 19.51^{\prime \prime} \mathrm{E}$. These areas exhibit bimodal distribution of rainfall, with the long rains occurring from early March to late May and the short rains from mid-October to late December (Jaetzold et al. 2012). Nyandarua receives mean annual temperature of $18.2{ }^{\circ} \mathrm{C}$ with an annual rainfall amount of $1500 \mathrm{~mm}$. Kabete receives average temperature of $21.2{ }^{\circ} \mathrm{C}$ and annual rainfall of $1100 \mathrm{~mm}$. Kirinyaga exhibits relatively lower annual rainfall amount ranging between 600 and $1000 \mathrm{~mm}$ and mean annual temperature of $24.4{ }^{\circ} \mathrm{C}$. During the study period, total rainfall amount of $345,184,328$ and $216 \mathrm{~mm}$ was received respectively during the 2017 long rains, 2017 short rains, 2018 long rains and 2018 short rains in the upper highland agro-ecological zone (AEZ). This is compared to rainfall amount of 388 , 211, 372 and $269 \mathrm{~mm}$ received in the lower highland AEZ, and 399, 209, 369 and $234 \mathrm{~mm}$ respectively in the upper highland AEZ. Across the seasons, the mean air temperatures were higher in the upper midland $\left(15.7-27.9^{\circ} \mathrm{C}\right)$, intermediate in the lower highland $\left(13.1-25.4^{\circ} \mathrm{C}\right)$ and lowest in the upper highland (11.1-22.3 $\left.{ }^{\circ} \mathrm{C}\right)$ AEZs.

The soils in Kabete are dark red friable clay, with clear, smooth boundaries classified as Humic Nitisol (Jaetzold et al. 2012), while the Kirinyaga soils are well drained, shallow to very deep, dark reddish brown silty loam classified as Rhodic Ferralsol. The soils in Nyandarua are dark brown to very dark red brown firm clay to silt loam clay classified as Ferric Luvisol. Details of the measured soil properties (0-1.2 m depth) before the experiment are provided in online resource material 1.

Experimental design and crop husbandry

The trials were laid out in a randomized complete block design with four replications. The plots were $6.2 \mathrm{~m}$ long by $3.0 \mathrm{~m}$ wide and were separated by $1 \mathrm{~m}$ path. The treatments comprised of sole potato (Solanum tuberosum L.), sole lima bean (P. lunatus L.), sole dolichos (Lablab purpureus L.) and intercrop of potato with either lima bean or dolichos. The potato cultivar used in this study is a heat and water stress tolerant locally known as Unica (CIP 392797.22) (CIP 2008). Intercropping was done in 1 row of potato alternating with 1 row of legumes. Potatoes were planted at a uniform depth of $0.1 \mathrm{~m}$ on pre-hilled ridges. Pre-hilling practice was informed by its ability to optimize soil temperatures and soil moisture distribution and due to its capacity to enable the legumes to be intercropped with ease of weeding, hilling and harvesting (Nyawade et al. 2018a). Two legume bean seeds were planted per hole at within row spacing of $0.2 \mathrm{~m}$ and inter-row spacing of $0.75 \mathrm{~m}$ between potato and legume strips, and $0.5 \mathrm{~m}$ between 2 legume strips. 
Fertilizer application was based on soil analysis and was adjusted seasonally taking into account the amount of mineral $\mathrm{N}$ in the soil prior to planting. On average, this activity consisted of basal application of $50 \mathrm{~kg} \mathrm{ha}^{-1} \mathrm{~N}, 90 \mathrm{~kg} \mathrm{P}^{-1}, 100 \mathrm{~kg} \mathrm{~K} \mathrm{ha}^{-1}$ and single topdressing with $50 \mathrm{~kg} \mathrm{~N}^{-1}$ in the form of calcium ammonium nitrate (26-0-0). Topdressing was done 15-25 days after potato emergence depending on the general soil moisture conditions. Legumes received only one basal phosphorus applications (triple super phosphate, 0-46-0) at rates averaging $20 \mathrm{~kg} \mathrm{P} \mathrm{ha}^{-1}$.

Weeding was performed at 14-21 days after potato emergence by hand hoeing, and entailed earthing up the soil around potato vines to about $0.2 \mathrm{~m}$ high and slight tamping of soil around legumes' stem base. The legumes were sprayed with Duduthrin 1.7 EC (Lambda-cyhalothrin $17.5 \mathrm{~g} \mathrm{~L}^{-1}$ ) alternating with Bestox $100 \mathrm{EC}$ (Alpha-cypermethrin $50 \mathrm{~g} \mathrm{~L}^{-1}$ ) to control aphids while potato crops were sprayed alternately with Ridomil Gold MZ 68WG (Mefenoxam $40 \mathrm{~g} \mathrm{~kg}^{-1}+$ Mancozeb $640 \mathrm{~g} \mathrm{~kg}^{-1}$ ) and Dithane-M (Mancozeb) to control potato late blight disease. Supplemental irrigation (water obtained from local water ponds) was supplied uniformly to the treatments with the use of sprinklers. Irrigation scheduling was done when the soil matric potential in the pure potato plots dropped below - $30 \mathrm{kPa}$ (field capacity).

Potatoes were harvested at maturity (90-112 days after planting) by digging out the tubers using hand hoes while legumes were left growing in the field (for a period of about 45 days after potato harvest) until they attained physiological maturity. The biomass from each plot was weighed, chopped and together with the potato residues, incorporated back into the soil in the subsequent seasons.

\section{Soil sampling and analyses}

Soil samples were taken in 10 replicates from interrows of each plot with a $15 \mathrm{~mm}$ inner-diameter soil piston auger at soil depth $0-0.3,0.3-0.6,0.6-0.9$ and 0.9-1.2 m. The soil samples were mixed into a composite for each depth, transported in cooler boxes and stored at $4{ }^{\circ} \mathrm{C}$ until analysis. Subsamples of $20 \mathrm{~g}$ fresh soil weight were extracted in $1 \mathrm{M} \mathrm{KCl}$ for $1 \mathrm{~h}$ (1 soil: 2 solution) and centrifuged. The supernatant was analyzed for $\mathrm{NH}_{4}{ }^{+}-\mathrm{N}$ and $\mathrm{NO}_{3}{ }^{-}-\mathrm{N}$ by standard colorimetric methods using Auto Analyzer 3 (Bran + Luebbe, Germany). The $\mathrm{N}$ content was converted to $\mathrm{kg} \mathrm{ha}^{-1}$ basis using soil bulk density values measured with soil cores ( $0.03 \mathrm{~m}$ inside diameter by $0.2 \mathrm{~m}$ long) for each sampling depth.

Soil moisture, rainfall and ambient temperature

Soil moisture content was measured every $0.3 \mathrm{~m}$ to depth of $1.2 \mathrm{~m}$ using neutron moisture meters installed in each plot. The soil moisture in the top $0.3 \mathrm{~m}$ soil layer was measured gravimetrically in all replications before planting to calibrate the neutron moisture meter and to estimate the amount of water required for irrigation. Rainfall amount of each experimental site was recorded using onsite rain gauges while air temperatures were obtained from $\mathrm{HOBO}$ temperature sensors installed within the experimental sites.

\section{Determination of leaf area index}

Leaf area index (LAI) was estimated using Sunfleck Ceptometer (Decagon Devices, Pullman, WA, USA) at different potato growth stages. This measurement was used to assess the effect of vegetal cover on soil erosion and temporal variability of soil moisture content under different cropping systems. All the measurements were taken on clear-sky days between 1130 and $0130 \mathrm{~h}$ to eliminate the effect of solar elevation on light interception. For each measurement, LAI readings were taken at an angle of $60^{\circ}$ across the crop rows to ensure that more leaf area was exposed to the light sensors.

Root sampling and estimation of root length density

Root length density was estimated and related with the amount of $\mathrm{N}$ leached. Briefly, root samples at different potato growth stages were extracted using metal cores (Bohm 1979) with dimensions of $0.085 \mathrm{~m}$ diameter and length of $0.1 \mathrm{~m}$ (giving a volume of $0.00057 \mathrm{~m}^{3}$ ). The cores were driven within the root-zones at $0-0.3$, $0.3-0.6,0.6-0.9$ and $0.9-1.2 \mathrm{~m}$ depths. After the excavations, the working surface of the soil profile was back-filled with the soil and gently smoothened. Soil cores containing the roots were placed in a bucket of water and gently agitated to break down larger soil particles, and to remove debris and dead roots. The 
roots were arranged and floated on shallow water in $0.4 \mathrm{~m} \times 0.4 \mathrm{~m}$ glass tray and then scanned using Epson Expression 1680 Scanner (Seiko Epson Corp., Tokyo, Japan) and analyzed for root length density using WinRHIZO Root Analyzer System (Regent Instruments Inc., Quebec, Canada) [Eq. (1)].

$$
\begin{aligned}
& \text { Root length density }\left(\mathrm{m} \mathrm{m}^{-3}\right) \\
& =\frac{\text { Root length }(\mathrm{m})}{\text { Soil volume of corresponding depth }\left(\mathrm{m}^{3}\right)}
\end{aligned}
$$

Computation of soil nitrogen balance

Soil nitrogen balance was computed as the difference between $\mathrm{N}$ input and output pools within the crop root zone (0-1.2 m depth) (OECD 2001). Taking into considerations the major nitrogen input and output pathways in smallholder potato cropping systems, soil nitrogen balance was computed using Eq. (2):

$$
\begin{aligned}
N_{\text {balance }}= & {\left[N_{\text {fert }}+N_{\text {init }}+N_{\text {res }}+N_{\text {min }}+N_{\text {fix }}\right] } \\
& -\left[N_{\text {uptake }}+N_{\text {ero }}+N_{\text {run }}+N_{\text {leach }}+N_{\text {vol }}\right] .
\end{aligned}
$$

where inputs: $\mathrm{N}_{\text {fert }}=\mathrm{N}$ gains from fertilizer; $\mathrm{N}_{\text {init- }}$ $=$ soil $\mathrm{N}$ available at start of the season; $\mathrm{N}_{\text {res }}=$ available soil $\mathrm{N}$ after harvest; $\mathrm{N}_{\min }=\mathrm{N}$ mineralization from crop residues, and the outputs; $\mathrm{N}_{\text {uptake }}=$ nitrogen accumulated in the plant; $\mathrm{N}_{\text {ero }}=\mathrm{N}$ carried by eroded sediment; $\mathrm{N}_{\text {run }}=\mathrm{N}$ lost in runoff; $\mathrm{N}_{\text {leach }}=\mathrm{N}$ leached beyond the active root zone; $\mathrm{N}_{\mathrm{vol}}=\mathrm{N}$ volatilized.

The contributions of biological nitrogen fixation to total $\mathrm{N}$ accumulation was estimated by the $\mathrm{N}$ difference method (Peoples et al. 2002) which is based on the fact that the sources of $\mathrm{N}$ for fixing crops are soil, fertilizer and the atmosphere (Eq. 3).

$\% N d f a=100-(\% N d f s+\% N d f f)$

where Ndff is nitrogen derived from the fertilizer; Ndfs, nitrogen derived from the soil and Ndfa, nitrogen derived from the atmosphere.

The amount of $\mathrm{N}$ leached was analyzed from the soil solution extracted using SoluSAMPLER located at vertical depths of $0.3,0.6,0.9,1.2$ and $1.5 \mathrm{~m}$ (Biswas and Schrale 2007). In this study, soil $\mathrm{N}$ beyond $1.2 \mathrm{~m}$ soil depth was considered leached, as no active roots were found beyond this depth. Nitrogen content from the sampled soil solution was determined by UV/vis spectrophotometer and indigotic colorimetric method. The $\mathrm{N}$ contents in soil were converted to $\mathrm{kg} \mathrm{N} \mathrm{ha}^{-1}$ basis using soil bulk density values measured for each sampling depth.

Nitrogen uptake by potato and legumes was computed at potato vegetative growth, tuber initiation, bulking, and maturation stages. For potatoes, samples were separated into tubers, roots and shoot while the legumes were partitioned into shoot, roots, and into grains for sampling conducted at maturity. The samples were dried in an oven at $70{ }^{\circ} \mathrm{C}$ for $48 \mathrm{~h}$, weighed, and subsamples analyzed for $\mathrm{N}$ content using Kjeldhal digestion method (Keeney and Nelson 1982). The total $\mathrm{N}$ uptake per plant was calculated as the product between plant part $\mathrm{N}$ concentration and biomass weight.

The litterbag method (Anderson and Ingram 1993; Verhoef 1995) was used to measure $\mathrm{N}$ mineralization from crop residues. The bags measured $0.3 \mathrm{~m}$ by $0.3 \mathrm{~m}$ and were made of plastic with $1 \mathrm{~mm}$ mesh. At harvest of each crop, 8 bags corresponding to the number of sampling times were filled with about $250 \mathrm{~g}$ of crop residues from each treatment after they had been chopped into pieces of about $50 \mathrm{~mm}$ long. About $250 \mathrm{~g}$ soils without crop residue amendments were also added in litterbags as controls. The bags were buried at a depth of $0.3 \mathrm{~m}$ at a distance of $0.3 \mathrm{~m}$ between the bags along the potato-legume rows. The bags were retrieved and sampled at 2, 4, 6, 8, 10, 12, 14 and 16 weeks after residue incorporation. At each sampling time, plant materials remaining in the litter bags were oven dried at $60{ }^{\circ} \mathrm{C}$ to a constant weight. The oven-dried samples were weighed separately to determine dry matter (DM) losses using Eq. (4).

Weight loss $=100 \times(M 0-M t) / M 0$

where $\mathrm{M} 0$ is the initial plant dry matter $(\mathrm{DM})(\mathrm{g})$ in the litterbag; Mt is the plant DM mass (g) in the bag at time $t$ when the bags were retrieved.

At each litter-sampling time, soil samples were taken at $0-0.3 \mathrm{~m}$ on the spots where the litterbags were laid and in control plots, and analyzed for mineral $\mathrm{N}$. The samples were put in airtight polythene bags, stored in the laboratory at $4{ }^{\circ} \mathrm{C}$, and analyzed within 2 days of sampling. Briefly, $20 \mathrm{~g}$ soil samples (passed through $0.5 \mathrm{~mm}$ sieve) were extracted in $60 \mathrm{~mL} 1 \mathrm{M}$ $\mathrm{KCl}$. The mixture was shaken on an end-over-end shaker for $1 \mathrm{~h}$, centrifuged and the clear supernatant 
transferred into $100 \mathrm{~mL}$ flasks. The supernatant was analyzed for total $\mathrm{N}$ using Kjeldahl method. The $\mathrm{N}$ content was converted to $\mathrm{kg} \mathrm{ha}^{-1}$ basis using soil bulk density values measured for each sampling interval. Net $\mathrm{N}$ mineralization was calculated as the difference between the amounts of mineral $\mathrm{N}$ released between the amended soil and the control soil.

The amount of $\mathrm{N}$ mineralized over time of sampling was calculated by the first-order model [Eq. (5)] (Jones 1984).

$N_{m}=N_{0}\left(1-e^{-k t}\right)+N_{1}$

where $N_{\mathrm{m}}\left(\mathrm{mg} \mathrm{kg}^{-1}\right)$ is the amount of $\mathrm{N}$ mineralized at time $t(\mathrm{~d}) ; N_{0}$, the initial mineralizable $\mathrm{N}$ content $\left(\mathrm{mg} \mathrm{kg}^{-1}\right) ; k$, the first-order rate constant $\left(\mathrm{d}^{-1}\right)$ and $N_{1}$ $\left(\mathrm{mg} \mathrm{kg}^{-1}\right)$, the zero-order constant $\left(\mathrm{mg} \mathrm{kg}^{-1}\right)$, i.e., $\mathrm{N}$ mineralized at time 0 .

A subsample of $25 \mathrm{~g}$ soil was dried in an oven at $105^{\circ} \mathrm{C}$ for $24 \mathrm{~h}$ to determine the soil moisture content at the time of sampling. In addition, the initial materials added to the bags ( 0 week sampling time) were analyzed for organic $\mathrm{C}$ using the wet digestion procedure (Nelson and Sommers 1996). Lignin was assessed by the acid detergent fibre method (Goering and van Soest 1970), while the water-soluble polyphenols were quantified using procedures outlined by Folin-Denis (King and Heath 1967).

Ammonia volatilization was measured using ventilation chambers placed at inter-rows of each plot (Jantalia et al. 2012). In 2017 SR, samples were collected at 4, 11, 18, 26, 34, 50, and 64 days after planting (DAP) and at 6, 13, 23, 30, 40, 50, 59, 70 and 82 DAP in 2017 LR. In 2018 SR, the data were collected at $8,22,29,36,44,51,58,71$, and 86 DAP and at $6,13,20,28,40,52,61,70$, and 83 DAP in 2018 LR. At each sampling date, the polyfoam strips and acid solution placed in plastic cups from each chamber were collected in $125 \mathrm{~mL}$ of $2 \mathrm{M} \mathrm{KCl}$ solution. Fifty (50) $\mathrm{mL}$ of this solution was analyzed using an automated ammonia analyzer (TL 2800, Timberline Instruments). $\mathrm{NH}_{3}$ volatilization during consecutive sampling dates $\left(\mathrm{mg} \mathrm{NH}_{3}-\mathrm{N} \mathrm{m}^{-2}\right)$ was determined using Eq. 6.

$$
\begin{aligned}
& \mathrm{NH}_{3} \text { volatilization } \\
& =\frac{\mathrm{NH}_{3}-\mathrm{N} \text { conc }\left(\mathrm{mg} \mathrm{mL}^{-1}\right) * \text { total vol of solution }(250 \mathrm{~mL})}{\text { Surface area of the soil covered by the trap }\left(0.90 \mathrm{~m}^{2}\right)}
\end{aligned}
$$

Cumulative $\mathrm{NH}_{3}$ volatilization $\left(\mathrm{kg} \mathrm{N} \mathrm{ha}^{-1}\right)$ was determined by summing up the amount of $\mathrm{NH}_{3}$ volatilized during each sampling period throughout the growing season using Eq. (7).

Cumulative $\mathrm{NH}_{3}$ emission $=\sum_{i}^{n} \frac{X_{i}+X_{i+1}}{2}\left(X_{i+1}-t_{i}\right)$

where $X i$ is the $\mathrm{NH}_{3}-\mathrm{N}$ flux measurement on day $t$, $X i+1$ is the succeeding $\mathrm{NH}_{3}-\mathrm{N}$ flux measurement on day $t i+1$, and $n$ is the final date of $\mathrm{NH}_{3}-\mathrm{N}$ flux measurement.

Runoff and sediment samples were collected using soil sedimentation containers installed at the lowest edge of each experimental plot. The runoff water collected was overflowed into a second container with a weir. The water level in this container was monitored at 30 min intervals by a GY-type sensor (UIZ-ECH20, UIZIN, Tokyo, Japan) and converted into water discharge to determine water runoff. The runoff water samples (about $15 \mathrm{~mL}$ ) were transferred into $20-\mathrm{mL}$ vials followed by a drop of $0.5 \mathrm{M}$ sulfuric acid and transported in ice water $\left(4{ }^{\circ} \mathrm{C}\right)$ within $24 \mathrm{~h}$ to the laboratory and chilled at $-4{ }^{\circ} \mathrm{C}$ till analyses [Eq. (8)]. The sediments were weighed after drying in an oven at $70{ }^{\circ} \mathrm{C}$. A sample of air-dried sediment from each plot (about $100 \mathrm{~g}$ ) was collected in $100 \mathrm{~mL}$ can and analyzed for $\mathrm{N}$ [Eq. (9)].

$$
\begin{aligned}
N_{\text {runoff }}\left(\mathrm{kg} \mathrm{ha}^{-1}\right)= & \text { Runoff } N\left(\mathrm{mg} \mathrm{L}^{-1}\right) \\
& * \text { runoff depth }(\mathrm{mm}) * 0.253
\end{aligned}
$$

$\begin{aligned} N_{\text {eroded sediment }}\left(\mathrm{kg} \mathrm{ha}^{-1}\right)= & \text { soil loss }\left(\mathrm{kg} \mathrm{ha}^{-1}\right) \\ & * \text { sediment } N\end{aligned}$

Residual soil nitrogen was determined by collecting soil from the center of each plot at $0-0.3 \mathrm{~m}$ at tuber harvesting. The samples were transferred to the laboratory at $4{ }^{\circ} \mathrm{C}$, stored at $-18{ }^{\circ} \mathrm{C}$, and analyzed for $\mathrm{N}$ within 1 week following Kjedlhal method (Nelson and Sommers 1996). Corresponding bulk density of soil was measured from an intact soil core ( $0.03 \mathrm{~m}$ inside diameter by $0.2 \mathrm{~m}$ long) and used to convert $\mathrm{mg}$ of $\mathrm{N} \mathrm{kg}^{-1}$ soil to $\mathrm{kg} \mathrm{N} \mathrm{ha}^{-1}$. 
Data analysis

The data was analyzed using R software, version 3.5.2. The treatment effects on soil water content, soil temperature and $\mathrm{N}$ balance were tested using general linear model analysis. Whenever interaction of cropping system and season was found significant, data were analyzed in separate seasons. Tukey's honest significant difference test was applied for multiple mean comparisons between treatments and tests with $p<0.05$ were considered statistically significant. To derive the mineralization rate constants $(\mathrm{k}), \mathrm{N}$ mineralization data was fitted to the kinetic model by data processing software KyPlot (KyensLab Inc., Tokyo, Japan) using nonlinear least-square technique. An exponential function was fitted to give the relative predictive power of $\mathrm{N}$ mineralization as a function of root length density with an equation of the form $y=a b x$, where $a \neq 0$.

\section{Results}

Leaf area index

Leaf area index (LAI) was significantly greater in intercropping (0.13-3.9) compared to pure potato stands (0.10-3.43) irrespective of the agro-ecological zones (AEZs) (Fig. 1). Generally, LAI was greater in the upper highland (0.31-3.90), intermediate in the lower highland (0.18-3.15) and lowest in the upper midland AEZ (0.12-2.96). In the upper highland AEZ, LAI was significantly higher in pure potato than in either sole dolichos or potato-dolichos intercropping. Leaf area index peaked 1 week earlier in the upper midland AEZ relative to the upper highland and lower highland agro-ecological zones.

\section{Runoff and sediment yield}

Mean seasonal soil loss and runoff differed significantly among the treatments and were consistently highest in sole potato, intermediate in intercropping and lowest in sole legumes (Fig. 2). Compared to sole potato plots, cumulative soil loss in the upper highland AEZ reduced by $122.9 \mathrm{t} \mathrm{ha}^{-1}$ in potato-lima bean intercropping. Similarly, soil loss in the upper midland and lower highland AEZs reduced by $38.9-81.6 \mathrm{t} \mathrm{ha}^{-1}$ in potato-dolichos intercropping. Cumulative runoff showed a similar trend.

Spatiotemporal distributions of soil water content

Soil water content (SWC) showed no significant differences among the treatments and across the AEZs at vegetative stage of potato development, and

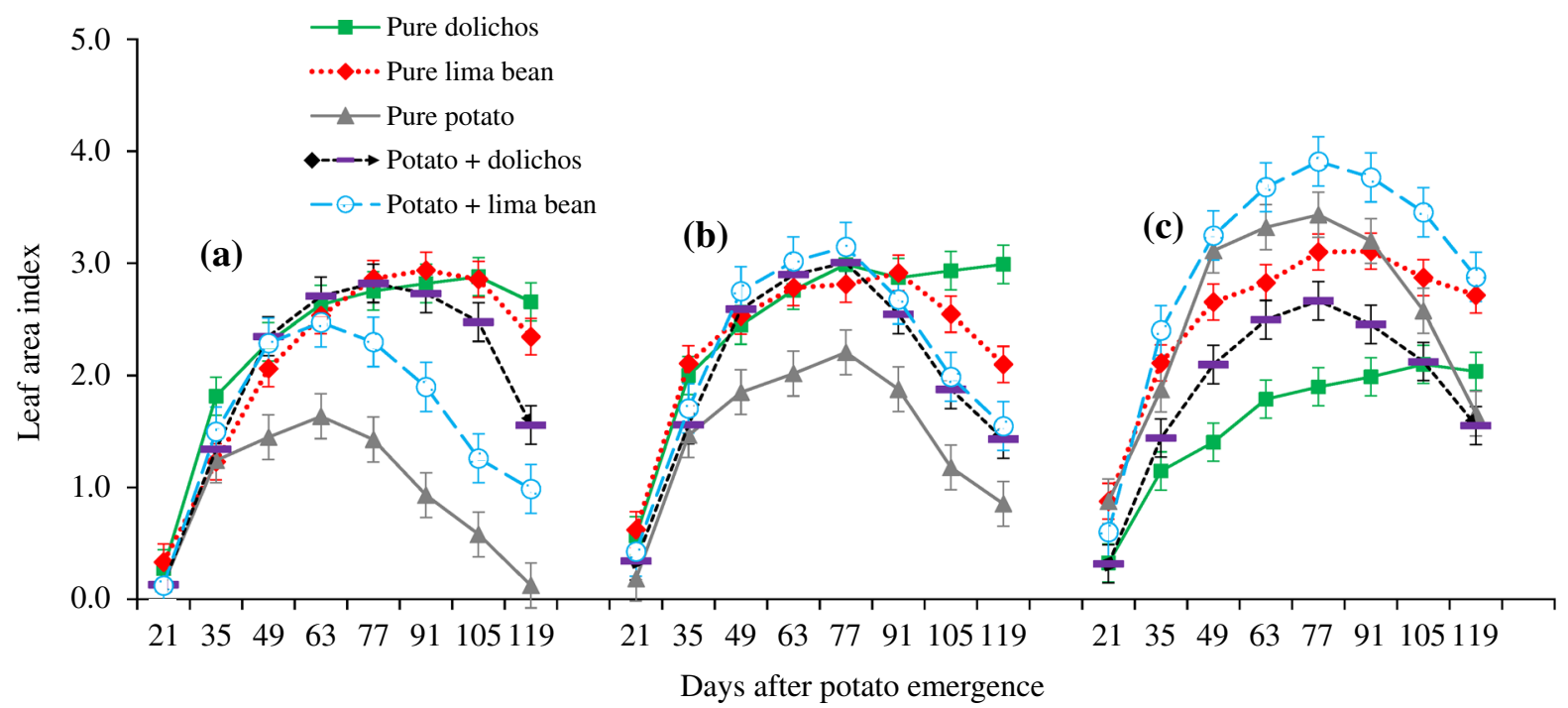

Fig. 1 Development of leaf area index by different treatments in the upper midland (a), lower highland (b) and upper highland (c) agro-ecological zones. Vertical bars indicate standard error of means. Values are 4 replicates expressed as averages over the four seasons 
Fig. 2 Mean seasonal soil loss and runoff measured under different cropping systems in the upper midland (a), lower highland (b) and upper highland (c) agro-ecological zones. Means with different letters show significant differences between treatments at Tukey's $p \leq 0.05$. Data presented as averages of 4 replicates

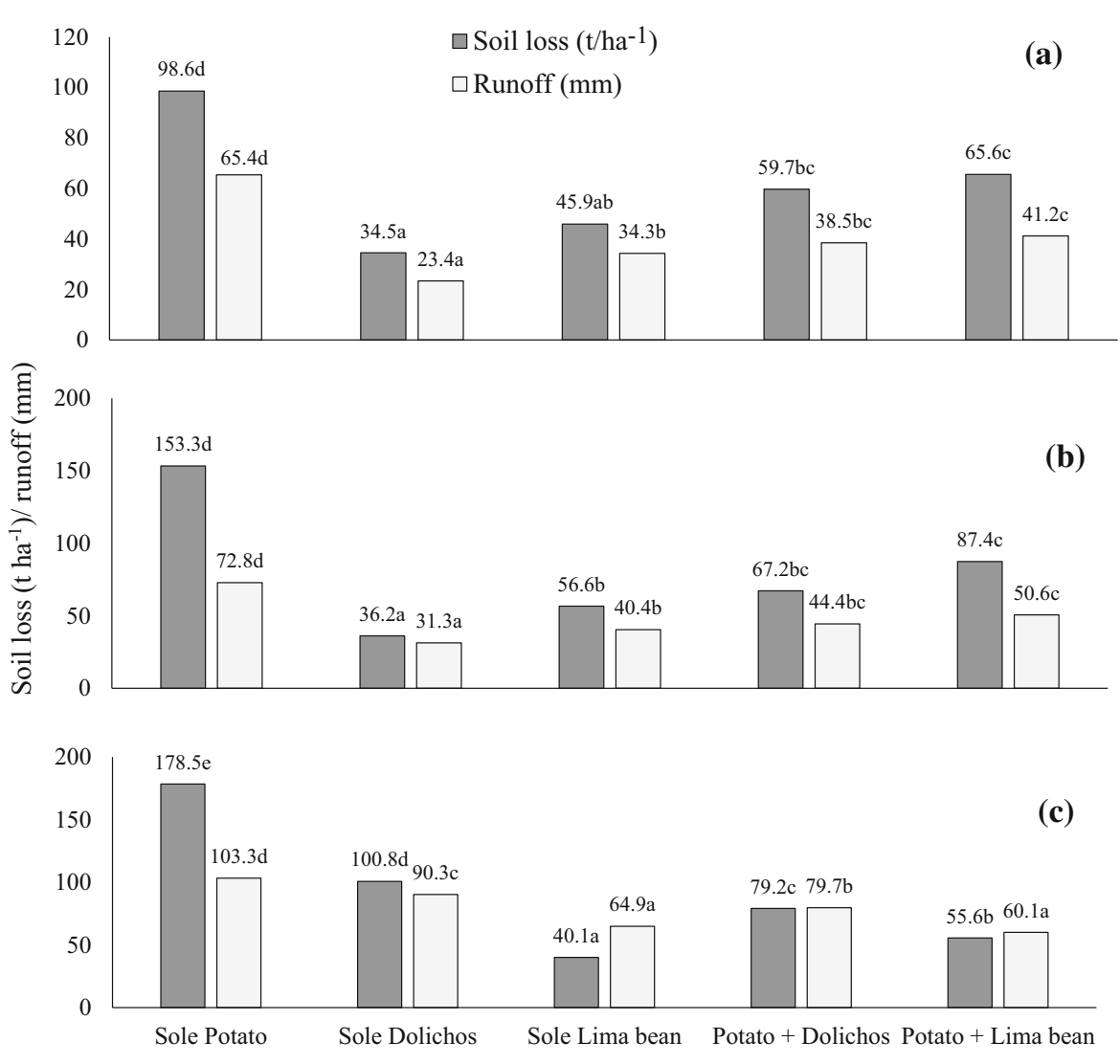

generally increased with increasing soil depth (Fig. 3a). At tuber bulking stage, SWC at soil depth $0.30 \mathrm{~m}$ was significantly higher in intercropping compared to pure potato stand (Fig. 3b), but greater in pure potato plots at soil depths $0.3-0.6,0.6-0.9$ and $0.9-1.2 \mathrm{~m}$. In the upper highland AEZ, the SWCs was significantly greater in pure potato plots than in intercropping at soil depth $0.60 \mathrm{~m}$, but showed no significant differences among the treatments at soil depths $0.9 \mathrm{~m}$ and $1.2 \mathrm{~m}$.

Influence of potato-legume intercropping on soil temperature

Soil temperature in the $0-0.3 \mathrm{~m}$ depth was significantly influenced by cropping system and was highest in pure potato plots $\left(21.7-28.1^{\circ} \mathrm{C}\right)$ and lowest in potato-dolichos intercropping $\left(17.9-22.5^{\circ} \mathrm{C}\right)$ in the upper midland and lower highland AEZs (Table 1 and online resource material 9). In the upper highland AEZ, potato-lima bean intercropping exhibited the lowest soil temperatures $\left(17.5-18.9{ }^{\circ} \mathrm{C}\right)$ while monocultures of potato and dolichos showed the highest soil temperatures.

Residue yield and biochemical composition

Biomass yield differed significantly among the cropping systems and was greatest in pure legume stands (range of 4.4-7.5 t DM ha ${ }^{-1}$ ) followed by intercropping (3.4-6.6 $\mathrm{t} \mathrm{DM} \mathrm{ha}^{-1}$ ) and lowest in sole potato cropping (1.8-3.9 t DM ha ${ }^{-1}$ ) (Table 2). Residue total organic carbon content varied from 275 to $385 \mathrm{mg} \mathrm{g}^{-1}$ in pure potato to $473-557 \mathrm{mg} \mathrm{g}^{-1}$ in pure legumes. Intercropping showed intermediate range of residue $\mathrm{OC}$ composition, ranging between 358 and $496 \mathrm{mg} \mathrm{g}^{-1}$ across the AEZs. The highest concentration of total $\mathrm{N}$ was observed in pure legumes (28-33 $\left.\mathrm{mg} \mathrm{g}^{-1}\right)$ followed by intercropping $\left(18-26 \mathrm{mg} \mathrm{g}^{-1}\right)$ and lowest in pure potato (11-14 $\left.\mathrm{mg} \mathrm{g}^{-1}\right)$. Lignin contents were significantly higher in pure potato $\left(65-71 \mathrm{mg} \mathrm{g}^{-1}\right)$ relative to intercropping (41-50 $\mathrm{mg} \mathrm{g}^{-1}$ ) and lowest in pure legumes $\left(35-51 \mathrm{mg} \mathrm{g}^{-1}\right)$. 
Soil water content $(\mathrm{mm})$

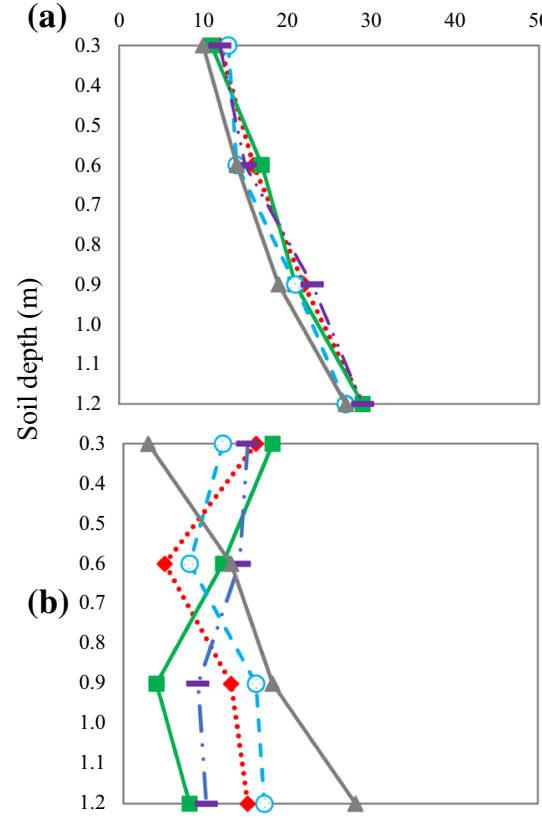

Upper midland

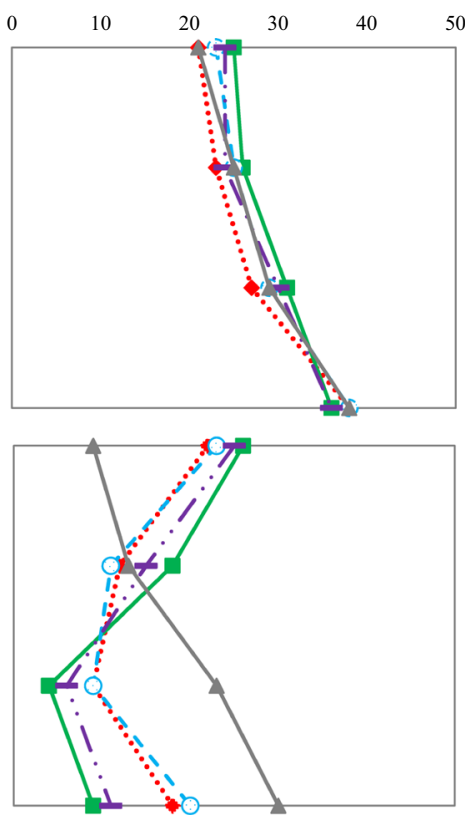

Lower highland

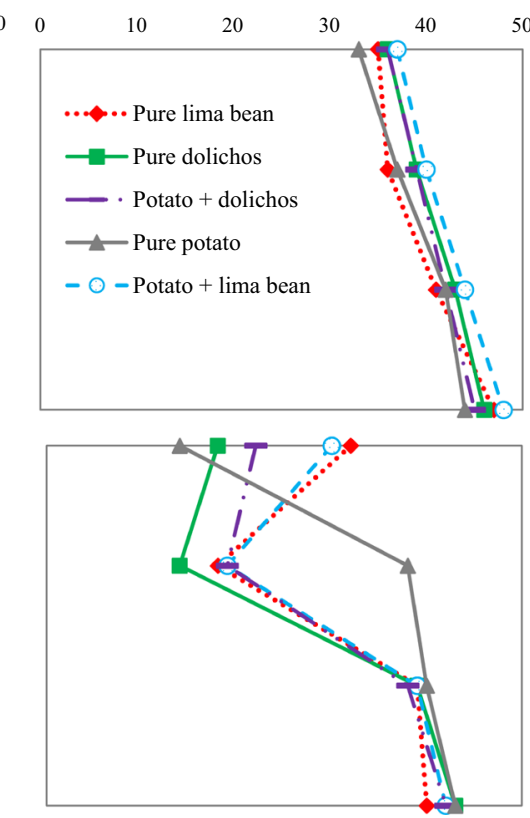

Upper highland

Fig. 3 Soil water content as measured at vegetative growth (a) and tuber bulking (b) stages of potato development at the depths of 0-1.2 $\mathrm{m}$ across the three agro-ecological zones. Values are 4 replicates expressed as averages over the four seasons

Table 1 Intercropping effect on soil temperature during the four seasons of study

\begin{tabular}{|c|c|c|c|c|c|c|c|c|c|c|c|c|}
\hline \multirow[b]{2}{*}{ Cropping system } & \multicolumn{4}{|c|}{ Upper midland } & \multicolumn{4}{|c|}{ Lower highland } & \multicolumn{4}{|c|}{ Upper highland } \\
\hline & $\begin{array}{l}2017 \\
\text { LR } \\
\text { Soil te }\end{array}$ & $\begin{array}{l}2017 \\
\text { SR } \\
\text { perature }\end{array}$ & $\begin{array}{l}2018 \\
\mathrm{LR} \\
\left({ }^{\circ} \mathrm{C}\right)\end{array}$ & $\begin{array}{l}2018 \\
\text { SR }\end{array}$ & $\begin{array}{l}2017 \\
\text { LR }\end{array}$ & $\begin{array}{l}2017 \\
\text { SR }\end{array}$ & $\begin{array}{l}2018 \\
\text { LR }\end{array}$ & $\begin{array}{l}2018 \\
\text { SR }\end{array}$ & $\begin{array}{l}2017 \\
\text { LR }\end{array}$ & $\begin{array}{l}2017 \\
\text { SR }\end{array}$ & $\begin{array}{l}2018 \\
\text { LR }\end{array}$ & $\begin{array}{l}2018 \\
\text { SR }\end{array}$ \\
\hline Sole potato & $27.1 \mathrm{c}$ & $28.1 \mathrm{~d}$ & $26.2 \mathrm{~d}$ & $27.5 \mathrm{c}$ & $24.7 \mathrm{c}$ & $25.8 \mathrm{~d}$ & $24.8 \mathrm{~d}$ & $25.4 \mathrm{c}$ & $22.6 \mathrm{~d}$ & $23.5 \mathrm{~d}$ & $21.7 \mathrm{~d}$ & $22.3 \mathrm{e}$ \\
\hline Sole dolichos & $20.6 \mathrm{a}$ & $20.9 \mathrm{a}$ & $20.3 \mathrm{a}$ & $21.4 \mathrm{a}$ & $17.1 \mathrm{a}$ & $20.4 \mathrm{a}$ & $17.3 \mathrm{a}$ & $21.4 \mathrm{a}$ & $17.8 \mathrm{~b}$ & $20.6 c$ & $19.3 \mathrm{c}$ & $18.73 b d$ \\
\hline Sole lima bean & $22.9 \mathrm{~b}$ & $21.5 b$ & $21.8 \mathrm{ab}$ & $21.6 a b$ & $19.5 b$ & $21.2 \mathrm{~b}$ & $19.6 b$ & $21.3 \mathrm{a}$ & $15.3 \mathrm{a}$ & $17.4 \mathrm{a}$ & $17.8 \mathrm{a}$ & $15.4 \mathrm{a}$ \\
\hline Potato + dolichos & $22.5 b$ & $22.4 b c$ & $22.2 b c$ & $21.9 \mathrm{ab}$ & $19.5 b$ & $21.1 \mathrm{~b}$ & $20.4 b c$ & $21.8 \mathrm{ab}$ & $17.9 \mathrm{bc}$ & $19.8 \mathrm{bc}$ & $17.9 \mathrm{a}$ & $19.1 \mathrm{~cd}$ \\
\hline $\begin{array}{l}\text { Potato }+ \text { lima } \\
\text { bean }\end{array}$ & $23.1 b$ & $23.6 \mathrm{c}$ & $23.7 \mathrm{c}$ & $22.3 b$ & $20.7 b$ & $23.9 \mathrm{c}$ & $21.8 \mathrm{c}$ & $22.4 \mathrm{~b}$ & $18.1 \mathrm{c}$ & $18.3 \mathrm{ab}$ & $18.9 \mathrm{bc}$ & $17.5 b$ \\
\hline
\end{tabular}

Letters indicate comparisons for means between the cropping systems at $p \leq 0.05$ by Tukey's HSD test. Values are 4 replicates expressed as averages over the four seasons

$S R$ short rains season, $L R$ long rains season

\section{Nitrogen mineralization and uptake}

Net $\mathrm{N}$ mineralized ranged between 6.9 and $9.0 \mathrm{~kg} \mathrm{~N} \mathrm{ha}^{-1}$ in sole potato, 39.3-56.0 $\mathrm{kg} \mathrm{N} \mathrm{ha}^{-1}$ in intercropping and $39.9-64.9 \mathrm{~kg} \mathrm{~N} \mathrm{ha}^{-1}$ in pure legumes (Fig. 4a). Peak $\mathrm{N}$ release in intercropping system was $8-9 \mathrm{~kg} \mathrm{~N} \mathrm{ha}^{-1}$ within $8-10$ weeks of residue decomposition and matched with peak $\mathrm{N}$ uptake by potato (19.9-31.2 $\mathrm{kg} \mathrm{N}^{-1}$ ) that occurred at this time. This is in contrast to pure potato which obtained peak net mineralization of $2.6-3.6 \mathrm{~kg} \mathrm{~N} \mathrm{ha}^{-1}$ at $12-14$ weeks of residue 
Table 2 Dry matter (DM) yield, nitrogen concentrations (N)) and chemical composition of crop residues at time of field incorporation

\begin{tabular}{|c|c|c|c|c|c|c|c|c|c|c|}
\hline $\begin{array}{l}\text { Agro- } \\
\text { ecological } \\
\text { zone }\end{array}$ & Cropping system & $\begin{array}{l}\text { DM } \\
\left(\mathrm{t} \mathrm{ha}^{-1}\right)\end{array}$ & $\begin{array}{l}\text { OC } \\
\left(\mathrm{mg} \mathrm{g}^{-1}\right)\end{array}$ & $\begin{array}{l}\text { Total } \mathrm{N} \\
\left(\mathrm{mg} \mathrm{g}^{-1}\right)\end{array}$ & $\begin{array}{l}\text { Lignin } \\
\text { (L) }\left(\mathrm{mg} \mathrm{g}^{-1}\right)\end{array}$ & $\begin{array}{l}\text { Polyphenol } \\
\text { (P) }\left(\mathrm{mg} \mathrm{g}^{-1}\right)\end{array}$ & $\mathrm{C}: \mathrm{N}$ & L:N & $\mathrm{P}: \mathrm{N}$ & $\begin{array}{l}(\mathrm{L}+\mathrm{P}): \\
\mathrm{N}\end{array}$ \\
\hline \multirow[t]{5}{*}{ Upper midland } & Potato + dolichos & $5.3 \mathrm{~d}$ & $378 b$ & $20 \mathrm{~b}$ & $54 \mathrm{bc}$ & $15 \mathrm{a}$ & $18.9 \mathrm{a}$ & $2.7 \mathrm{~b}$ & $0.8 \mathrm{ab}$ & $1.7 \mathrm{~b}$ \\
\hline & Potato + lima bean & $3.4 \mathrm{~b}$ & $358 b$ & $18 \mathrm{~b}$ & $58 \mathrm{bc}$ & $20 \mathrm{a}$ & $19.9 \mathrm{a}$ & $3.2 \mathrm{~b}$ & $1.1 \mathrm{~b}$ & $2.4 \mathrm{c}$ \\
\hline & Sole dolichos & $7.5 \mathrm{e}$ & $518 \mathrm{c}$ & $32 \mathrm{c}$ & $41 \mathrm{a}$ & $14 \mathrm{a}$ & $16.2 \mathrm{a}$ & $1.2 \mathrm{a}$ & $0.4 \mathrm{a}$ & $0.5 \mathrm{a}$ \\
\hline & Sole lima bean & $4.9 \mathrm{c}$ & $473 \mathrm{c}$ & $28 \mathrm{c}$ & $51 \mathrm{ab}$ & $18 \mathrm{a}$ & $16.9 \mathrm{a}$ & $1.9 \mathrm{a}$ & $0.7 \mathrm{a}$ & $0.9 \mathrm{a}$ \\
\hline & Sole potato & $1.8 \mathrm{a}$ & $275 \mathrm{a}$ & $11 \mathrm{a}$ & $71 \mathrm{c}$ & $22 \mathrm{a}$ & $25.0 \mathrm{~b}$ & $6.4 \mathrm{c}$ & $2.1 \mathrm{c}$ & $7.8 \mathrm{~d}$ \\
\hline \multirow[t]{5}{*}{ Lower highland } & Potato + dolichos & $6.6 \mathrm{~d}$ & $496 \mathrm{bc}$ & $26 \mathrm{~b}$ & $48 \mathrm{~b}$ & $16 \mathrm{a}$ & $19.1 \mathrm{a}$ & $1.9 \mathrm{ab}$ & $0.6 \mathrm{a}$ & $1.0 \mathrm{~b}$ \\
\hline & Potato + lima bean & $4.8 \mathrm{~b}$ & $453 b$ & $23 b$ & $54 \mathrm{c}$ & $19 \mathrm{a}$ & $19.7 \mathrm{a}$ & $2.4 \mathrm{~b}$ & $0.8 \mathrm{a}$ & $1.4 \mathrm{~b}$ \\
\hline & Sole dolichos & $8.9 \mathrm{e}$ & $557 \mathrm{~d}$ & $33 \mathrm{c}$ & $35 \mathrm{a}$ & $15 \mathrm{a}$ & $16.9 \mathrm{a}$ & $1.1 \mathrm{a}$ & $0.5 \mathrm{a}$ & $0.5 \mathrm{a}$ \\
\hline & Sole lima bean & $6.3 \mathrm{c}$ & $531 \mathrm{~cd}$ & $30 \mathrm{c}$ & $47 \mathrm{~b}$ & $18 \mathrm{a}$ & $17.7 \mathrm{a}$ & $1.6 \mathrm{a}$ & $0.6 \mathrm{a}$ & $0.7 \mathrm{a}$ \\
\hline & Sole potato & $2.9 \mathrm{a}$ & $344 a$ & $13 \mathrm{a}$ & $67 \mathrm{~d}$ & $21 \mathrm{a}$ & $26.5 b$ & $5.2 \mathrm{c}$ & $1.6 \mathrm{~b}$ & $5.2 \mathrm{c}$ \\
\hline \multirow[t]{5}{*}{ Upper highland } & Potato + dolichos & $5.8 \mathrm{~b}$ & $442 b$ & $22 \mathrm{bc}$ & $50 \mathrm{~b}$ & $16 \mathrm{a}$ & $20.1 \mathrm{a}$ & $2.3 b$ & $0.8 \mathrm{a}$ & $1.4 \mathrm{~b}$ \\
\hline & Potato + lima bean & $6.6 \mathrm{c}$ & $480 \mathrm{c}$ & $25 \mathrm{~cd}$ & $50 \mathrm{~b}$ & $18 \mathrm{a}$ & $19.2 \mathrm{a}$ & $2.0 \mathrm{~b}$ & $0.7 \mathrm{a}$ & $1.1 \mathrm{~b}$ \\
\hline & Sole dolichos & $4.4 \mathrm{a}$ & $529 \mathrm{~d}$ & $28 \mathrm{~d}$ & $40 \mathrm{a}$ & $15 \mathrm{a}$ & $18.9 \mathrm{a}$ & $1.4 \mathrm{a}$ & $0.6 \mathrm{a}$ & $0.7 \mathrm{a}$ \\
\hline & Sole lima bean & $8.1 \mathrm{~d}$ & $551 \mathrm{~d}$ & $33 \mathrm{e}$ & $48 \mathrm{~b}$ & $16 \mathrm{a}$ & $16.7 \mathrm{a}$ & $1.5 \mathrm{a}$ & $0.5 \mathrm{a}$ & $0.6 \mathrm{a}$ \\
\hline & Sole potato & $3.9 \mathrm{a}$ & $385 \mathrm{a}$ & $14 \mathrm{a}$ & $65 \mathrm{c}$ & $19 \mathrm{a}$ & $27.5 b$ & $4.7 \mathrm{c}$ & $1.4 \mathrm{~b}$ & $4.3 \mathrm{c}$ \\
\hline
\end{tabular}

Means followed by the same letter down the column within an agro-ecological zone do not differ significantly by Tukey's HSD at $p \leq 0.05$

decomposition. Nitrogen uptake at this period was relatively low ranging between 4.3 and $25.4 \mathrm{~kg} \mathrm{~N} \mathrm{ha}^{-1}$. Sole legumes exhibited peak mineralization at 6-8 weeks after residue incorporation. Nitrogen uptake by potato, though high at this period, was not at its peak. Cumulatively, intercropped potato showed significantly higher $\mathrm{N}$ uptake per plant compared to sole potato and was lowest in the sole legumes irrespective of AEZs (Fig. 4b). This N uptake ranged from 87.5 to $171.2 \mathrm{~kg} \mathrm{~N} \mathrm{ha}^{-1}$ in intercropping and $53.1-79.5 \mathrm{~kg} \mathrm{~N} \mathrm{ha}^{-1}$ in sole legumes. In the upper highland AEZ, $\mathrm{N}$ uptake by dolichos grown either in pure stand or in intercropping was significantly lower than that of lima bean.

Nitrogen balance

Soil $\mathrm{N}$ depletion occurred in pure potato stands $(-38$ to $-24.5 \mathrm{~kg} \mathrm{~N} \mathrm{ha}^{-1}$ ) while surplus occurred in monocultures of dolichos (5.5-58.2 $\left.\mathrm{kg} \mathrm{N} \mathrm{ha}^{-1}\right)$ and lima bean (19.7-55.5 $\mathrm{kg} \mathrm{N} \mathrm{ha}^{-1}$ ) (Table 3 and online resource material 6). Intercropping showed intermediate soil $\mathrm{N}$ balance $\left(3.1-9.5 \mathrm{~kg} \mathrm{~N} \mathrm{ha}^{-1}\right)$. The main component of soil $\mathrm{N}$ input was mineralization followed by residual $\mathrm{N}$ and $\mathrm{N}_{2}$ fixation across the cropping systems and AEZs. Leaching, erosion and runoff accounted for $0.3-36.9 \mathrm{~kg} \mathrm{~N} \mathrm{ha}^{-1}$ of the $\mathrm{N}$ output in the upper highland and were highest in sole potato stands, intermediate in intercropping and lowest in sole legumes. Volatilization contributed $0.7-34.4 \mathrm{~kg} \mathrm{~N} \mathrm{ha}^{-1}$ of $\mathrm{N}$ output in the upper midland AEZ and was highest in pure potato stands and lowest in sole legumes.

The amount of $\mathrm{N}$ leached decreased with increasing root length density $\left(0.53 \leq \mathrm{R}^{2} \leq 0.90\right)$ (Fig. 5). The relationship was strongest in pure potato plots $\left(\mathrm{R}^{2}=0.90\right)$ followed by potato + lima bean $\left(\mathrm{R}^{2}=0.65\right)$, pure dolichos $\left(\mathrm{R}^{2}=0.63\right)$ and lowest in sole lima bean $\left(\mathrm{R}^{2}=0.53\right)$. 

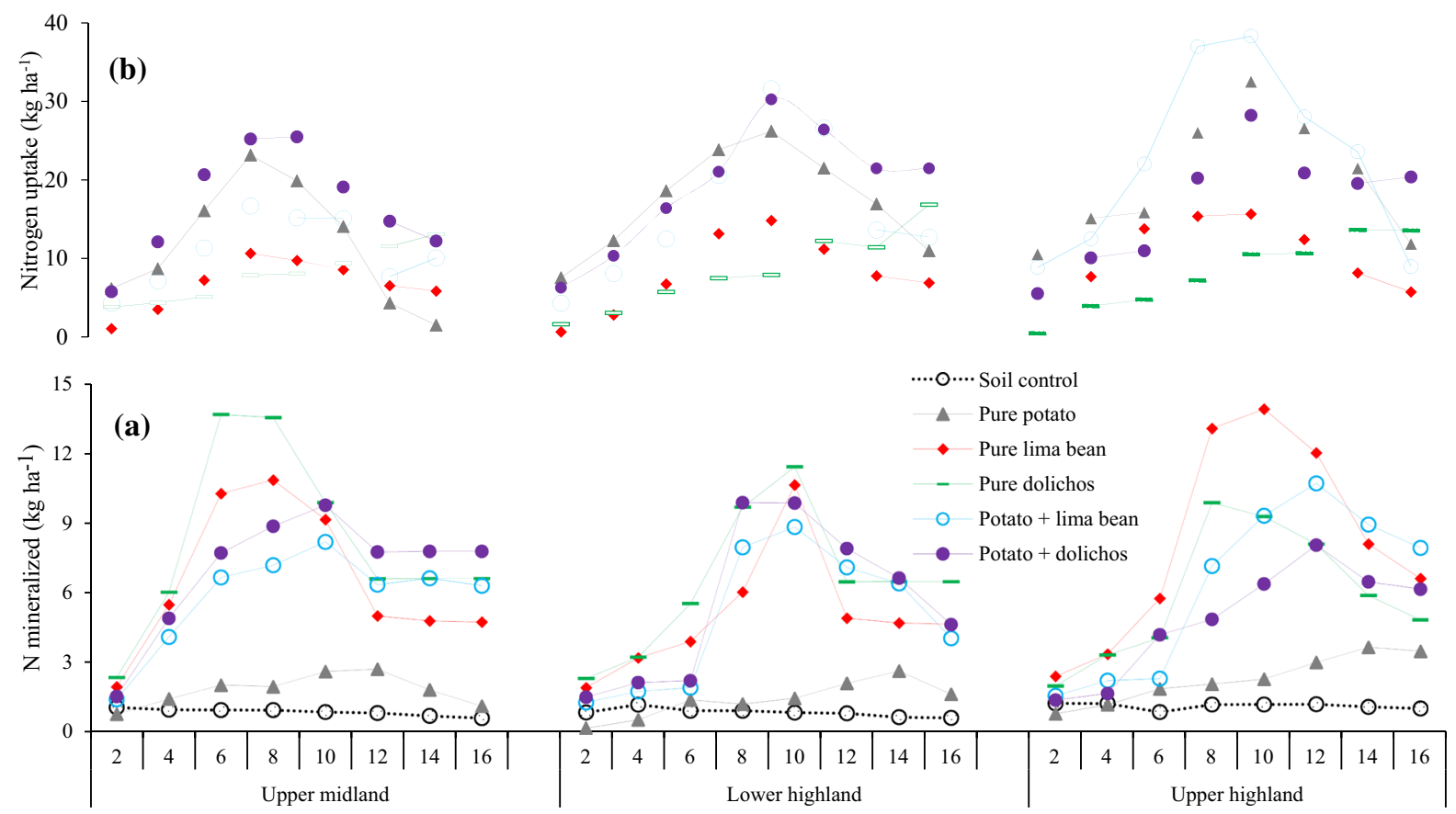

Weeks after treatment application

Fig. 4 Accumulations of residue $\mathrm{N}$ mineralized (a) and $\mathrm{N}$ taken up by the crops (b) after 16 weeks of residue decomposition and potato planting respectively in the upper midland, lower highland and upper highland agro-ecological zones. Soil control

\section{Discussion}

Influence of potato-legume intercropping on canopy growth and soil erosion

Legume intercropping increased leaf area index as legumes exhibited rapid growth which enhanced canopy overlap thus covering the empty spaces in the inter-rows of potato and legumes (see online resource 7). This reduced the raindrop hitting force and slowed down the velocity of runoff. While the low canopy of dolichos reduced the raindrop falling height and minimized the raindrop hitting force, the effective canopy overlap by lima bean enhanced the capability of leaves to resist bending thus augmenting stem flow. This increased the effective rain-receiving area which eliminated erosion and runoff generation. The canopy of dolichos was extended after potato harvest to the subsequent season and was thus effective in controlling post-harvest runoff and soil erosion. The canopy closure of potato was effective only after 40 to 45 days treatments without residue amendments were included during decomposition for comparisons and for computation of net $\mathrm{N}$ mineralization. Values are 4 replicates expressed as averages over the four seasons

(see online resource 8) and diminished at physiological maturity when plants began to senesce. Jégo et al. (2008) noted that the shorter period of growth characterizing potato intensifies soil erosion especially after the plants begin to senesce.

The low sediment yield and runoff generation under potato-dolichos intercropping in the upper midland and lower highland AEZs resonates with the high LAI observed in this treatment. This observation suggests a greater soil stabilizing effect of dolichos which may be asserted to the continuity of groundcover throughout the year compared to other treatments which were left bare soon after potato harvest. In the upper highland AEZ, growth of dolichos was suppressed by the low ambient temperatures (Cook et al. 2005). In similar studies, reduction of sediment yield, runoff generation and associated $\mathrm{N}$ loss under potato-dolichos intercropping has been adduced to the canopy heterogeneity contributed by differences in plant heights (Nyawade et al. 2019a, b). The first raindrops that hit the canopy is intercepted and dispersed by dolichos 


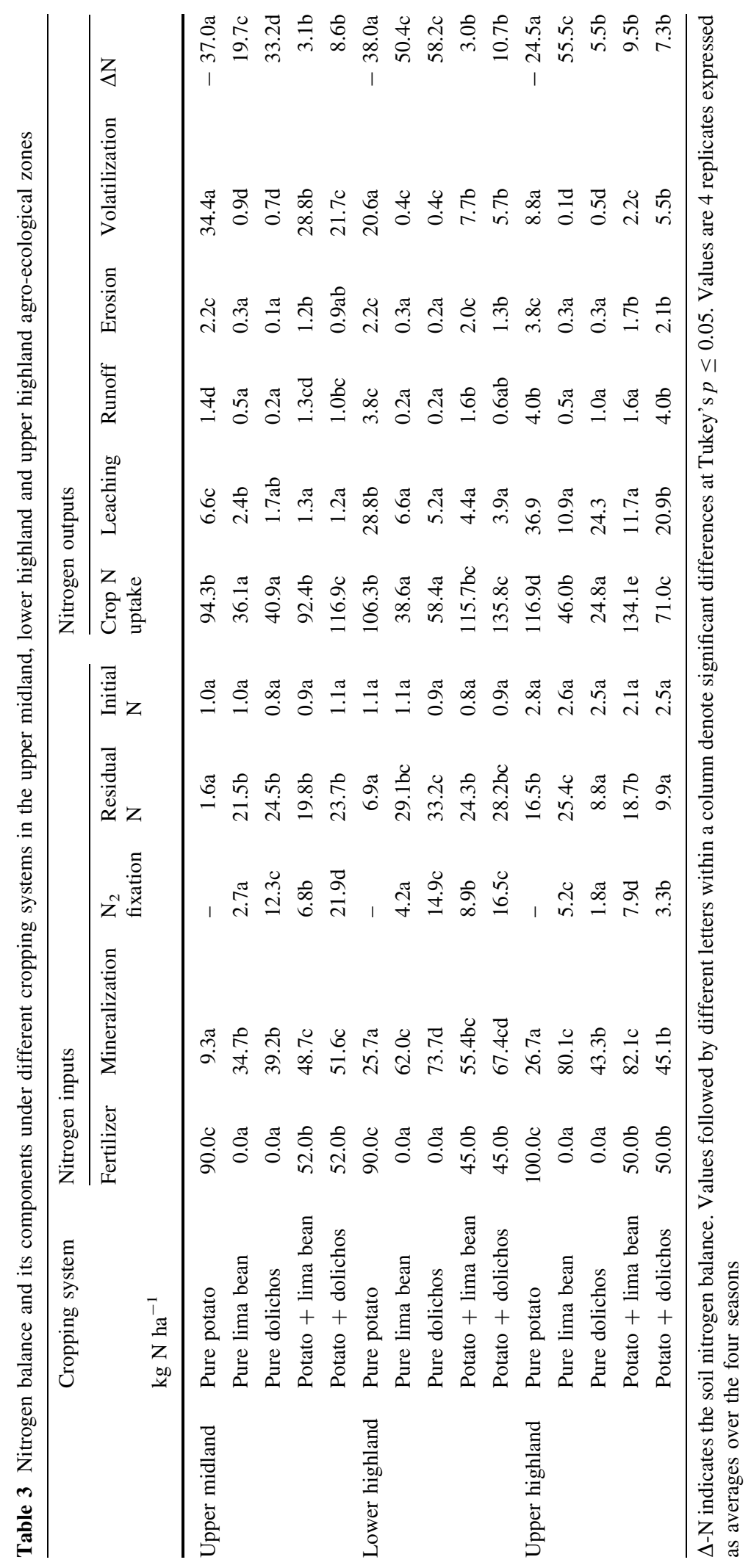


Fig. 5 Amount of nitrogen leached below the active root zone as a function of root length density under different cropping systems. Each point is an average of treatment from 4 replicates across the sampling sites

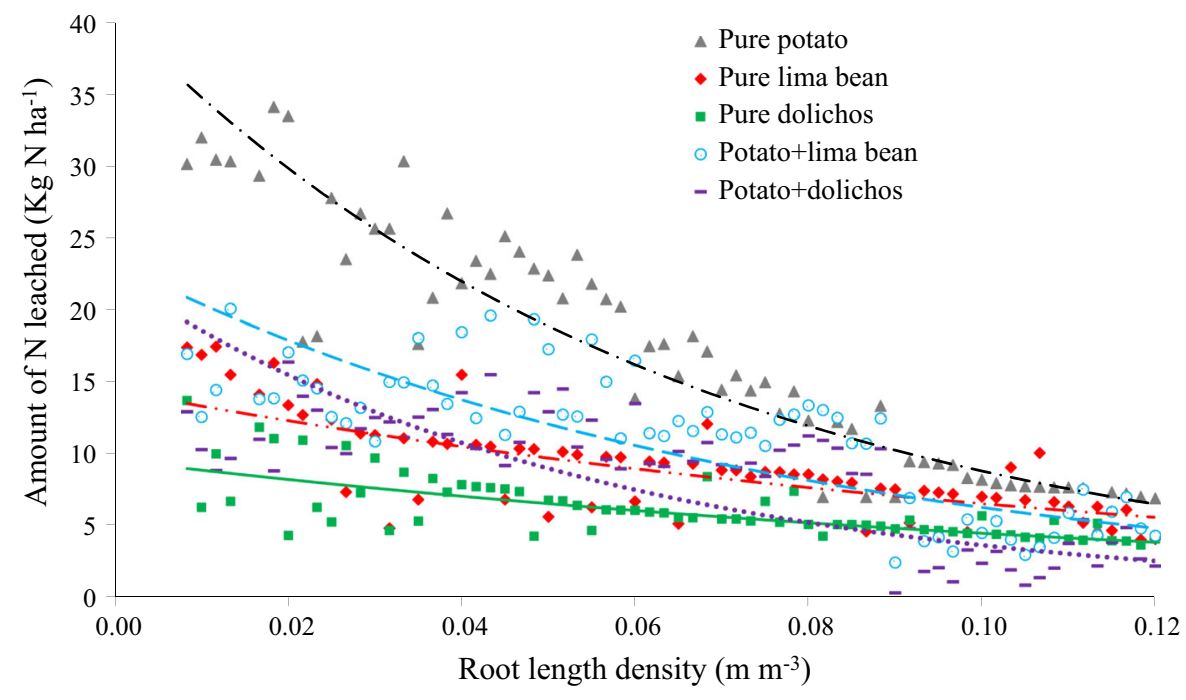

developed deep root systems thus enhancing root water uptake.

Residue $\mathrm{N}$ mineralization and $\mathrm{N}$ uptake

The $\mathrm{N}$ mineralization process was influenced by residue biochemical composition, the effect of which was greatest under sole legumes indicating that legumes enhanced supply of $\mathrm{N}$ to the soil. This observation was indicated by the ratios of residue C-to-N, lignin-to-N, polyphenol-to-N and lignin + polyphenol-to- $\mathrm{N}$ which were low in intercropping relative to pure potato stands. This observation agrees with previous findings which showed that legumes provide high amounts of $\mathrm{N}$-rich residues thus enhancing $\mathrm{N}$ mineralization and supply (Palm and Sanchez 1991; Tian et al. 1992; Handayamoto et al. 1994).

Generally, $\mathrm{N}$ mineralization was lowest within the first 2 weeks of residue decomposition under sole potato residue but increased sharply at the 6th week. During this period (6th week), the potato tissues had less than $10 \mathrm{~g} \mathrm{~kg}^{-1} \mathrm{~N}$ with $\mathrm{C}$-to- $\mathrm{N}$ ratio of approximately 30 , indicating that this concentration and ratio are reasonable critical levels for initial net mineralization of potato residue. With legume intercropping, immobilization was observed within the first 2 weeks of residue incorporation probably due to the low buildup of microbial population which are involved in residue degradation (Ruijter et al. 2010). 
The increase in residue $\mathrm{N}$ mineralization after the 4th week of residue decomposition irrespective of treatments could be due to release of soluble and readily decomposable $\mathrm{N}$-containing biochemical compounds like amino sugars, nucleic acids and proteins (Paul and Clark 1989). The peak $\mathrm{N}$ release at 6-10 weeks across the treatments after residue incorporation was consistent with the residue mass loss and signified intense organic matter degradation at these times. At later stages of decomposition, little extra $\mathrm{N}$ was released, an observation we attribute to the decrease in residue mass which was the source of microbial substrates.

The differences in $\mathrm{N}$ mineralization patterns between the sites was attributed to the seasonal variations in soil temperature and soil moisture contents. Moisture and temperature control decomposer activity and thus influence plant residue decomposition (Tian et al. 1993; Mitchell et al. 2000). The lower temperatures in the upper highland AEZ could have lowered the respiration rates thus delaying net mineralization (Tian et al. 1997). The low mineral $\mathrm{N}$ during the wet seasons in this study could therefore be attributed to the generally low soil temperatures which lowered the decomposition rate of crop residues.

The occurrence of peak residue $\mathrm{N}$ mineralization and $\mathrm{N}$ uptake in intercropping indicated synchrony of $\mathrm{N}$ supply and demand. At week 4 after potato planting, pure legumes showed higher cumulative $\mathrm{N}$ uptake due to their ability to grow fast and take up the $\mathrm{N}$ mineralized. A comparatively slow mineralization from sole potato residues resulted in low initial $\mathrm{N}$ supply as greater amount of $\mathrm{N}$ was immobilized in potato residue at this time. The increase in $\mathrm{N}$ uptake by intercropped potato could have also been due to root facilitative interactions such as rhizodeposition and $\mathrm{N}$-transfer (Jensen 1996). Whitbread et al. (2011) showed the ability of dolichos to capture $\mathrm{N}$ from the subsoil and pump it to the surface soil strata thus making it available for the shallow rooted crops.

\section{Soil $\mathrm{N}$ balance and its components}

A significantly higher $\mathrm{N}$ balance was recorded in intercropping relative to sole potato reflecting the effect of legumes on $\mathrm{N}$ dynamics. Intercropping increased groundcover across the seasons and agroecological zones which greatly conferred shading to the soil. This lowered the soil temperature and reduced ammonia volatilization while minimizing $\mathrm{N}$ losses to soil erosion and runoff. Nitrogen being highly mobile in its nitrate form was quickly leached below the potato-root zone (see online resource 5) whereas the legume intercrops developed deep root systems that enhanced the recovery of $\mathrm{N}$ leached below the potato root-zone.

The greater $\mathrm{N}$ fixation by intercropped legumes (see online resource 3) was perhaps in response to increased soil $\mathrm{N}$ competition by potato grown in association. This, according to previous studies permits legumes' greater reliance on symbiotic $\mathrm{N}_{2}$ fixation (Inal et al. 2007). Alonso-Ayuso et al. (2014) found that high competition with barley for soil $\mathrm{N}$ forced vetch to rely on $\mathrm{N}_{2}$ fixation for its $\mathrm{N}$ requirement, and in return accumulated large amount of $\mathrm{N}$ compared to sole vetch. Therefore, in conditions that enabled the growth of both companion species, the increased uptake of $\mathrm{N}$ by potato caused a temporary decrease in soil $\mathrm{N}$ thereby increasing the proportion of $\mathrm{N}_{2}$ fixed by the legume. HauggaardNielsen et al. (2009) argued that the high $\mathrm{N}_{2}$ fixation potential of legumes grown in intercropping is due to the high degree of complementarities arising from species interaction that enables natural regulation mechanisms between the intercrop components. Such mechanisms include improved $\mathrm{N}$ capture in mixed crops as a result of complementarity in foraging strategies in space (soil profile) and time (growth period of the crop) (Lithourgidis et al. 2011). Snoeck et al. (2000) showed that up to $30 \%$ of $\mathrm{N}_{2}$ fixed by legumes was transferred to the associated non-legume under field conditions. They attributed this to the interactions of roots and secretion of root exudates. Similarly, the legumes in this study had deeper rooting depth which enabled them to explore greater soil volume and diverge the $\mathrm{N}$ leached beyond the active root zone.

The generally higher $\mathrm{N}_{2}$ fixation by dolichos over lima bean could be ascribed to the genetic differences among crop cultivars as interactions between legume microsymbionts are highly specific (Qiang et al. 2003). In addition, the continued accumulation of biomass by dolichos days after lima bean senesced may explain the differences in relative contribution of fixed $\mathrm{N}_{2}$ between the two legumes. Cook et al. (2005) noted that dolichos is able to take up $\mathrm{N}$ from up to 1.5-2.4 m depth after a relative short growth period. Studies conducted in central Kenya indicated that the 
$\mathrm{N}$ contribution of dolichos is in the range of $8-25 \mathrm{~kg} \mathrm{~N} \mathrm{ha}^{-1}$ while that of lima bean is in the range of $1.6-7 \mathrm{~kg} \mathrm{~N} \mathrm{ha}^{-1}$ (Chemining'wa et al. 2007a, b).

The greater $\mathrm{N}$ uptake by dolichos than lima bean in the lower highland and upper midland agro-ecological zones (see online resource 4) may be related to the enhanced $\mathrm{N}_{2}$-fixation. This mechanism directly affects N uptake and metabolism (Wyeh and Rains 1978). The converse was observed in the upper highland AEZ due to the low temperatures that dolichos could not tolerate. Chemining'wa et al. (2007a, b) recorded higher nodule numbers per plant for dolichos than for lima bean under elevated temperature conditions. This was attributed to dolichos' high adaptation to water stress. The notably lower crop nitrogen uptake in the upper midland AEZ relates to the low soil moisture and high ambient temperatures.

Nitrogen volatilization was lowest in sole legumes because these treatments were not fertilized with $\mathrm{N}$, and thus lacked the $\mathrm{N}$ emission triggered by $\mathrm{N}$ fertilization. The differences in cumulative ammonia volatilization between the study sites were attributed to the differences in temperature and rainfall. The lower temperatures coupled with the higher rainfall amounts in the upper highland AEZ may have decreased ammonia volatilization (Whitehead et al. 1988) while the high ambient temperatures and low soil moisture in the upper midland AEZ favored net volatilization.

\section{Conclusion}

These results give an insight on the potential role of potato-legume intercropping in enhancing $\mathrm{N}$ inputs into the soil while minimizing the output pathways, thus offering a mechanism for optimizing soil nitrogen content in smallholder farming systems. Reduction of nitrogen loss in this manner could be an effective measure to improve soil productivity and increase the efficiency of nutrient use while dampening nitrogen losses to water bodies. Even though the observed biological $\mathrm{N}_{2}$ fixation contribution by the legumes in this study seemed insufficient to cover the total potato $\mathrm{N}$ need, this amount of nutrient remains important to the resource-constrained farmers. These contributions will better be understood if linkages between the litter fauna and residue biochemical composition is assessed and established under different temperature and moisture regimes.

Acknowledgements This work was implemented and funded as part of the CGIAR Research Program on Climate Change, Agriculture and Food Security (CCAFS) and undertaken jointly with the CGIAR Research Program on Roots, Tubers and Bananas (RTB), which are carried out with support from CGIAR Fund Donors and through bilateral funding agreements. For details, please visit https://ccafs.cgiar.org/donors. The views expressed in this document cannot be taken to reflect the official opinions of these organizations.

\section{Compliance with ethical standards}

Conflict of interest The authors declare that they have no competing interests in this paper and the study as a whole.

Open Access This article is licensed under a Creative Commons Attribution 4.0 International License, which permits use, sharing, adaptation, distribution and reproduction in any medium or format, as long as you give appropriate credit to the original author(s) and the source, provide a link to the Creative Commons licence, and indicate if changes were made. The images or other third party material in this article are included in the article's Creative Commons licence, unless indicated otherwise in a credit line to the material. If material is not included in the article's Creative Commons licence and your intended use is not permitted by statutory regulation or exceeds the permitted use, you will need to obtain permission directly from the copyright holder. To view a copy of this licence, visit http://creativecommons.org/licenses/by/4.0/.

\section{References}

Alonso-Ayuso M, Gabriel JL, Quemada M (2014) The kill date as a management tool for cover cropping success. PLoS ONE 9(10):e109587

Anderson JM, Ingram JS (1993) Tropical soil biology and fertility: a handbook of methods, 2nd edn. CAB International, Wallingford

Arregui LM, Quemada M (2006) Drainage and nitrate leaching in a crop rotation under different $\mathrm{N}$-fertilizer strategies: application of capacitance probes. Plant Soil 288(1-2):57-69

Baldock J, Macdonald L, Farrell M, Welti N, Monjardino M (2018) Nitrogen dynamics in modern cropping systems. CSIRO Agriculture and Food, Locked Bag, Glen Osmond, p 5064

Becker M, Ladha JK (1997) Synchronizing residue N mineralization with rice $\mathrm{N}$ demand in flooded conditions. In: Cadisch G, Giller KE (eds) Driven by nature: plant litter quality and decomposition. CAB International, Wallingford, pp 231-238

Biswas T, Schrale G (2007) Sentek SoluSAMPLER: a tool for managing salt and nutrient movement in the root zone. In: Instruction manual version 2.0. Sentek Pty Ltd., Stepney 
Bohm W (1979) Methods of studying root systems. Springer, Heldelberg

Burke JJ (2017) Growing the potato crop. Vita, Equity House, Upper Ormond Quay

Chemining'wa GN, Muthomi JW, Theuri SW (2007a) Effect of Rhizobia inoculation on and starter- $\mathrm{N}$ on nodulation, shoot biomass and yield of grain legumes. Asian J Plant Sci 6(7):1113-1118

Chemining'wa GN, Muthomi JW, Theuri SM (2007b) Effect of rhizobia inoculation and starter- $\mathrm{N}$ on nodulation, shoot biomass and yield of grain legumes. Asian J Plant Sci 6:1113-1118

CIP (2008) Catalogue of CIP potato varieties. https://research. cip.cgiar.org/germplasm-istribution/red_varie/brochure. php?variedad=392797.22. Accessed 14 June 2019

Constantin J, Beaudoin N, Launay M, Duval J, Mary B (2012) Long-term nitrogen dynamics in various catch crop scenarios: test and simulations with STICS model in a temperate climate. Agric Ecosyst Environ 147:36-46

Cook BG, Pengelly, Brown BC, Donnelly JL, Eagles DA, Franco MA, Hanson J, Mullen BF, Partridge IJ, SchultzeKraft R (2005) Tropical forages: an interactive selection tool. Lablab purpureus. CSIRO, DPI and F (Qld), CIAT, and ILRI, Brisbane, Australia. http://www.tropicalforages. Accessed 13 June 2019

Eaglesham AR, Ayanaba JA, Rao VR, Eskew DL (1981) Improving the nitrogen nutrition of maize by intercropping with cowpea. Soil Biol Biochem 13:169-171

Gentile R, Vanlauwe B, van Kessel C, Six J (2009) Managing N availability and losses by combining fertilizer-N with different quality residues in Kenya. Agric Ecosyst Environ 131:308-314

Giller KE (2015) Nitrogen fixation in tropical cropping systems, 2nd edn. CABI, Wallingford, p 423

Gitari HI, Gachene CKK, Karanja NN, Kamau S, Nyawade S, Sharma K, Schulte-Geldermann E (2018a) Optimizing yield and economic returns of rain-fed potato (Solanum tuberosum L.) through water conservation under potatolegume intercropping systems. Agric Water Manag 208:59-66

Gitari HI, Karanja NN, Gachene CKK, Kamau S, Sharma K, Schulte-Geldermann E (2018b) Nitrogen and phosphorous uptake by potato (Solanum tuberosum L.) and their use efficiency under potato-legume intercropping systems. Field Crops Res 222:78-84

Gitari HI, Gachene CKK, Karanja NN, Kamau S, Nyawade SO, Schulte-Geldermann E (2019) Potato-legume intercropping on a sloping terrain and its effects on soil physicochemical properties. Plant Soil 438:447

Goering HK, van Soest PJ (1970) Forage fibre analyses: apparatus reagents, procedures and some applications. USDA Handb. No. 379. U.S. Govt. Printing Offices, Washington, DC

Handayamoto E, Cadisch G, Giller KE (1994) Nitrogen release from prunings of legume hedgerow trees in relation to quality of the prunings and incubation method. Plant Soil 160:237-248

Hauggaard-Nielsen H, Gooding M, Ambus P, Corre-Hellou P, Crozat Y, Dahlmann C, Dibet A, von Fragstein P, Pristeri A, Monti M, Jensen ES (2009) Pea-barley intercropping for efficient symbiotic $\mathrm{N}$-2-fixation, soil $\mathrm{N}$ acquisition and use of other nutrients in European organic cropping systems. Field Crop Res 113:64-71

Henao J, Baanante C (2006) Agricultural production and soil nutrient mining in Africa implications for resource conservation and policy development: summary an International Center for Soil Fertility and Agricultural Development; IFDC

Inal A, Gunes A, Zhang F, Cakmak I (2007) Peanut/maize intercropping induced changes in rhizosphere and nutrient concentrations in shoots. Plant Physiol Biochem 45:350-356

Jaetzold R, Hornetz B, Shisanya CA, Schmidt H (2012) Farm management handbook of Kenya, vol I-IV (Western, Central, Eastern, Nyanza, Southern Rift Valley, Northern Rift Valley, Coast), Nairobi. www.uni-trier.de/index. php?id=58581. Accessed 9 May 2019

Jantalia CP, Halvorson AD, Follett RF, Bruno JRA, Jose CP, Segundo U (2012) Nitrogen source effects on ammonia volatilization as measured with semi-Static chambers. Agron J 104:1595-1603

Jégo G, Martínez M, Antigüedad I, Launay M, Sanchez-Pérez JM, Justes E (2008) Evaluation of the impact of various agricultural practices on nitrate leaching under the root zone of potato and sugar beet using the STICS soil-crop model. Sci Total Environ 394:207-221

Jensen ES (1996) Barley uptake of $\mathrm{N}$ deposited in the rhizosphere of associated field pea. Soil Biol Biochem 28:159-168

Jimenez C, Tejedor M, Rodriguez M (2007) Influence of land use changes on soil temperature regime of andosols on Tenerife, Canary Island, Spain. Europ J Soil Sci 58(2):445-449

Jones CA (1984) Estimation of an active fraction of soil nitrogen. Commun Soil Sci Plant Anal 15:23-32

Keeney DR, Nelson DW (1982) Nitrogen in organic forms. In: Page AL et al (eds) Methods of soil analysis. Part 2. Agronomy No. 9, American Society of Agronomy, Madison, pp 643-698

Kimetu JM, Mugendi DN, Bationo A, Palm CA, Mutuo PK, Kihara J, Nandwa S, Giller K (2006) Partial balance of nitrogen in a maize cropping system in humic nitisol of Central Kenya. Nutr Cycl Agroecosyst 76:261-270

King HGC, Heath GW (1967) The chemical analysis small samples of leaf material and the relationship between the disappearance and composition of leaves. Pedobiologia 7:192-197

Lithourgidis AS, Dordas CA, Damalas CA, Vlachostergios DN (2011) Annual intercrops: an alternative pathway for sustainable agriculture. Aust J Crop Sci 5(4):396-410

Loomis RS, Connor DJ (1992) Crop ecology: productivity and management in agricultural systems, vol 10. Cambridge University Press, Cambridge, pp 8-538

Lupwayi NZ, Haque I (1999) Leucaena hedgerow intercropping and cattle manure application in the Ethiopian highlands I. Decomposition and nutrient release. Biol Fertil Soils 28:182-195

Lupwayi NZ, Clayton GW, O’Donovan JT, Harker KN, Turkington TK, Soon YK (2006) Nitrogen release during decomposition of crop residues under conventional and zero tillage. Can J Soil Sci 86:11-19 
Mitchell RDJ, Harrison R, Webb J (2000) The effect of crop residue incorporation date on soil inorganic nitrogen, nitrate leaching and nitrogen mineralization. Biol Fertil Soils 32:294-301

Muthoni J, Shimelis H, Melis R (2013) Potato production in Kenya: farming systems and production constraints. J Agric Sci 5:182-197

Nelson DW, Sommers LE (1996) Carbon and organic matter. In: Sparks DL, Page AL, Helmke PA, Loeppert RH, Soltanpour PN, Tabatabai MA, Johnston CT, Sumner ME (eds) Methods of soil analysis, part 3, chemical analysis. SSSA, ASA, Madison, pp 961-1010

Nyawade SNS, Karanja NN, Gachene CKK, Schulte-Geldermann E, Parker LM (2018a) Susceptibility of soil organic matter fractions to soil erosion under potato-legume intercropping systems in central Central Kenya. J Soil Water Conserv 73:5678-5767

Nyawade SO, Karanja NN, Gachene CKK, Schulte-Geldermann E, Parker LM (2018b) Effect of potato hilling on soil temperature, soil moisture distribution and sediment yield on a sloping terrain. Soil Till Res 184:24-36

Nyawade SO, Gachene CKK, Karanja NN, Gitari HI, SchulteGeldermann E, Parker ML (2019a) Controlling soil erosion in smallholder potato farming systems using legume intercrops. Geoderma Reg 15:e00225

Nyawade SO, Karanja NN, Gachene CKK, Gitari HI, SchulteGeldermann E, Parker ML (2019b) Short-term dynamics of soil organic matter fractions and microbial activity in smallholder legume intercropping systems. Appl Soil Ecol 142:123-135

OECD (2001) Environmental indicators for agriculture, methods and results. OECD Publications Service, Paris

Onwuka B, Mang M (2018) Effects of soil temperature on some soil properties and plant growth. Adv Plants Agric Res 8(1):34-37

Palm CA, Sanchez PA (1991) Nitrogen release from some tropical legumes as affected by lignin and polyphenol contents. Soil Biol Biochem 23:83-88

Paul EA, Clark FE (1989) Soil microbiology and biochemistry. Academic Press, Orlando

Peoples MB, Giller KE, Herridge DF, Vessey JK (2002) Limitations to biological nitrogen fixation as a renewable source of nitrogen for agriculture. In: O'Brian M, Layzell D, Vessey K, Newton W, Finan T (eds) Nitrogen fixation global. CAB International, Wallingford

Plaza-Bonilla D, Jean-Marie N, Didier R, Justes E (2015) Cover crops mitigate nitrate leaching in cropping systems including grain legumes: field evidence and model simulations. Agric Ecosyst Environ 212:1-12

Qiang C, Xiapong Z, Zewdi T, Seppo K, Dengyu L, Kristina L (2003) Diversity of peanut (Arachis hypogaea) bradyrhizobia and their host plants. Plant Soil 255:605-617

Ruijter FJ, Huijsmans JFM, Rutgers B (2010) Ammonia volatilization from crop residues and frozen green manure crops. Atmos Environ 44:3362-3368

Sanchez PA (2002) Ecology: soil fertility and hunger in Africa. Science 295(5562):2019-2020. https://doi.org/10.1126/ science. 1065256
Sanginga N, Woomer PL (2009) Integrated soil fertility management in Africa: principles, practices and development process. Tropical Soil Biology and Fertility Institute of the International Centre for Tropical Agriculture, Nairobi

Shekofteh H, Majid A, Mohammad AH, Iversen V, Nezamabadi-Pour H, Fariborz A, Farid S, Shirani H (2013) Modeling of nitrate leaching from a potato field using HYDRUS-2D. Soil Sci Plant Anal 44:1-15

Snoeck D, Zapata F, Domenach AM (2000) Isotopic evidence of the transfer of nitrogen fixed by legumes to coffee trees. Biotechnol Agron Soc Environ. 4:95-100

Tian G, Kang BT, Brussard L (1992) Biological effects of plant residues with contrasting chemical compositions under humid tropical conditions-decomposition and nutrient release. Soil Biol Biochem 24:1051-1060

Tian G, Brussaard L, Kang BT (1993) Biological effects of plant residues with contrasting chemical compositions under humid tropical conditions-effects on soil fauna. Soil Biol Biochem 25:731-737

Tian G, Brussaard L, Kang BT, Swift MJ (1997) Soil faunamediated decomposition of plant residues under constrained environmental and residue quality conditions. In: Cadisch G, Giller KE (eds) Driven by nature: plant litter quality and decomposition. CAB International, Wallingford, pp 125-134

van Herwaarden AF, Farguhar GD, Angus JF, Richards RA, Howe GN (1998) "Haying-off" the negative grain yield response of dryland wheat to nitrogen fertiliser. I. Biomass, grain yield, and water use. Aust J Agric Res 49:1067-1081

Verhoef HA (1995) Litter bag method. In: Alef K, Nannipieri P (eds) Methods in applied soil microbiology and biochemistry. Academic Press, New York, pp 485-487

Whitbread AM, Ayisi K, Mabapa P, Odhiambo JJO, Maluleke N, Pengelly BC (2011) Evaluating Lablab purpureus L.: sweet germplasm to identify short-season accessions suitable for crop and livestock farming systems in southern Africa. Afr J Range Forage Sci 28:21-28

Whitehead DC, Lockyer DR, Raistrick N (1988) The volatilization of ammonia from perennial ryegrass during decomposition, drying, and induced senescence. Ann Bot 61:567-571

Wyeh RD, Rains DW (1978) Simultaneous measurements of nitrogen fixation estimated by acetylene-ethylene assay and nitrate absorption by soybean. Plant Physiol 62:442-448

Xing Z, Lien C, Herb W, Rees F, Monteith J, Lionel S (2011) A comparison of effects of one-pass and conventional potato hilling on water runoff and soil erosion under simulated rainfall. Can J Soil Sci 91:279-290

Publisher's Note Springer Nature remains neutral with regard to jurisdictional claims in published maps and institutional affiliations. 